\title{
A Retrospective Study on Equine Lameness and Influence of Age, Breed and Joint in Osteoarthritis
}

\author{
K. Balamurugan*, Mala Shammi, Ravi Sundar George, \\ T.A. Kannan and R. Sivashankar
}

Department of Veterinary Surgery and Radiology, Madras Veterinary College, Chennai, India

*Corresponding author

\section{A B S T R A C T}

\begin{tabular}{|l|}
\hline Ke y w o r d s \\
$\begin{array}{l}\text { Equine, Incidence, } \\
\text { Lameness, } \\
\text { Osteoarthritis, High } \\
\text { motion joints }\end{array}$ \\
\hline Article Info \\
\hline $\begin{array}{l}\text { Accepted: } \\
\text { 22 June } 2020 \\
\text { Available Online: } \\
\text { 10 July } 2020\end{array}$ \\
\hline
\end{tabular}

Osteoarthritis (OA) is a chronic degenerative joint disease characterized by progressive destruction of articular cartilage, thinning and eventual wearing of articular cartilage and resulted in painful and limited joint movement. Horses presented to Madras Veterinary College Teaching Hospital, Chennai with a history of lameness and corresponding clinical signs, suggestive of osteoarthritis were included in this study. 94 horses were diagnosed with lameness out of 177 . Out of this, 43 horses (46\%) had soft tissue affections, 27 horses (29\%) had osteoarthritis, and 24 horses (25\%) had foot affections. The influence of age, breed and joints in osteoarthritis will be discussed.

\section{Introduction}

Osteoarthritis was characterized by the progressive deterioration of articular cartilage and structural changes to the entire synovial joint, including synovium, meniscus, periarticular ligament adipose tissue and subchondral bone (Mobasheri et al., 2017). McIlwraith et al., (2012) reported that surveys established that $60 \%$ of lameness in equines was related to OA. The authors added that metacarpophalangeal joint was the most affected joint for OA in race horse followed by carpal joint and this was due to close fitting articular surface that could develop linear erosions and wear lines quickly in association with osteochondral fragmentation. Bjornsdottir et al., (2003), in a follow up study of 508 Icelandic riding horses concluded that osteoarthritis of the distal tarsal joints with correlating radiographic signs, the commonest cause for culling of horses used for riding was in the age group of 7-17 years.

\section{Materials and Methods}

The horses presented to Large Animal Surgery Unit of the Madras Veterinary 
College Teaching Hospital, Chennai constituted the population for this study. The horses were mainly used for pleasure riding in marina beach and patrolling purpose by the police. Horses with a history of lameness and corresponding clinical signs, suggestive of osteoarthritis were identified.

Visual examination, physical examination, lameness score, Flexion test and diagnostic analgesia were performed to identify the seat of lameness. Further, these horses were subjected to radiographic and ultrasonographic examination to confirm osteoarthritis.

\section{Results and Discussion}

A total of 94 horses were identified with lameness (53\%) out of 177 horses presented to the hospital. In these, 27 horses were diagnosed with osteoarthritis (29\%), 43 horses were treated for soft tissue affections $(46 \%)$ like desmitis, tendinitis, tendon and ligament rupture and 24 horses were diagnosed with foot affections (25\%) like foot abscess, over-grown hooves, thrush etc.

The horses with osteoarthritis were distributed among various age groups like less than 6 years, 7-12years and more than 12 years. Eight horses were less than 6 years (30\%), 16 horses were between $7-12$ years (59\%) and 3 horses were above 12 years (11\%). The breeds that were diagnosed with osteoarthritis were 17 Kathiawari (63\%), 9 Thoroughbred (33\%) and one Non-descript pony (4\%).

Horses in the age group of 7-12 years (59\%) had the highest incidence compared to other age groups. Bjornsdottir et al., (2000) in a study of 614 Icelandic riding horses also reported high prevalence of $30.3 \%$ in horses aged between 6 and 12 years. Bjornsdottir et al., (2003) in a follow up study concluded that the distal tarsal joint was the cause for culling of horses in the age group of 7-17 years. The reason for this could be because it is generally considered that this age is the most active period in the life of the horses.

Out of 27 osteoarthritic joints, 15 joints were of forelimb $(56 \%)$ and 12 were of hindlimb $(44 \%)$. In these, knee joint was 5 (19\%), hock joint was $7(26 \%)$, forelimb fetlock joint was 8 (30\%), hindlimb fetlock joint was 3 (11\%), forelimb coffin joint was $2(7 \%)$ and hind limb coffin joint was 2 (7\%).

High motion joints $(75 \%)$ such as carpal, fetlock or coffin were mostly affected with osteoarthritis and low motion joint like tarsal joint was affected with 25\%. Marais (2011) also stated that racing and performance horses were often affected with OA of high motion joints. This could be due to close fitting articular surface that develop linear erosions and wear-lines quickly as stated by Mcllwraith et al., (2012). Tarsal joints are vulnerable because of the smaller area of articular surface that sustained the weight bearing load for a long period of time as reported by Pool and Meager (1990).

Forelimb (56\%) was more affected than the hind limb (44\%). Osteoarthritis was more common in fore-fetlock joint (30\%) followed by hock joint (26\%). Cantley et al., (1999) opined that the fetlock joint was the most commonly affected, because of its relatively small surface area, wide range of motion and repeated over extension of the joint at high speed.

\section{Acknowledgement}

Authors acknowledge, The Dean and Director of clinics, Madras Veterinary College, Tamil Nadu Veterinary and Animal Sciences University for providing support to carry out the study. 


\section{References}

Bjornsdottir, S., M. Alexsson, P. Eksell, H. Sigurdsson and Carsten, J. 2000. Radiographic and clinical survey of degenerative joint disease in the distal tarsal joints in Icelandic horses. Equine vet. J., 32(3): 268-272.

Bjornsdottir, S., Th. Arnason and Lord, P. 2003. Culling rate of Icelandic horses due to bone spavin. Acta vet. Scand., 44: 161-169.

Cantley, C.E.L., E.C. Firth, J.W. Delahunt, D.U. Pfeiffer and Thompson, K.G. 1999. Naturally occurring osteoarthritis in the metacarpophalangeal joints of wild horses. Equine Vet. J., 31(1): 7381.
Marais, J. 2011. Current therapy of degenerative joint diseases in the horse: Part 1. Equine Health Update., 13(2): 28-33.

Mcllwraith, C.W., D.D. Frisbie and Kawcak, C.E. 2012. The horse as a model of naturally occurring osteoarthritis. Bone Joint Res., 1: 297-309.

Mobasheri, A., M.P. Rayman, O. Gualillo, J. Sellam, P. Kraan and Fearon, U. 2017. The role of metabolism in the pathogenesis of osteoarthritis. Nat Rev Rheumatol., 13: 302-311.

Pool, R.R and Meagher, D.M. 1990. Pathologic findings and pathogenesis of racetrack injuries. Vet Clin North Am Equine Pract., 6(1): 1-30.

\section{How to cite this article:}

Balamurugan, K., Mala Shammi, Ravi Sundar George, T.A. Kannan and Sivashankar, R. 2020. A Retrospective Study on Equine Lameness and Influence of Age, Breed and Joint in Osteoarthritis. Int.J.Curr.Microbiol.App.Sci. 9(07): 3391-3393.

doi: https://doi.org/10.20546/ijcmas.2020.907.396 